\title{
Nutrient Artery
}

National Cancer Institute

\section{Source}

National Cancer Institute. Nutrient Artery. NCI Thesaurus. Code C33189.

Any artery that supplies the inner cavity of a long bone. 